\title{
HUBUNGAN MOTIVASI KERJA DENGAN PRESTASI KERJA DI PEMERINTAHAN DESA GUMUKSARI KECAMATAN KALISAT KABUPATEN JEMBER Oleh:
}

ADI SANTOSO, S.Sos., M.Si.

\begin{abstract}
ABSTRAK
Tujuan dari penelitian ini adalah "Untuk mengetahui adakah hubungan
\end{abstract} yang positif dan signifikan antara motivasi kerja dengan prestasi kerja di Pemerintahan Desa Gumuksari Kecamatan Kalisat Kabupaten Jember".

Jenis penelitian ini adalah penelitian deskriptif dan analitikkuantitatif.

Lokasi penelitian dilakukan di kantorPemerintahan Desa Gumuksari Kecamatan Kalisat Kabupaten Jember.Populasi dalam penelitian ini adalah seluruh karyawan di kantor Pemerintahan Desa Gumuksari Kecamatan

Kalisat Kabupaten Jember. Penentuan sampel dalam penelitian ini menggunakan probability sampling dengan teknik simple random sampling yaitu 25 karyawan di kantor Pemerintahan Desa Gumuksari Kecamatan

Kalisat Kabupaten Jember.Dalam pengambilan data menggunakan kuesioner. Analisis data menggunakan analisis deskriptif kuantitatif yaitu koefisien korelasi menggunakan Rank Spearman, sedangkan kriteria pengambilan keputusannya dapat dilihat dari besarnya koefisien korelasi setelah dilakukan perhitungan menggunakan SPSS 16 for Windows adalah $1 \leq \mathrm{r} \leq 1$.

Hasil perhitungan menunjukkan bahwa diperoleh rs hitung 0,144 yang terletak pada interval korelasi antara 0,00-0,199 mengandung arti mempunyai hubungan yang sangat rendah, berarti ada hubungan yang positif dan signifikan antara motivasi kerja dengan prestasi kerja di Pemerintahan Desa Gumuksari Kecamatan Kalisat Kabupaten Jember.Merujuk pada perhitungan uji $t$ test maka terbukti bahwa $t$ hitung lebih besar dari t tabel yaitu $(0,787>0,687)$ berarti ada hubungan motivasi kerja dengan prestasi kerja yang nyata di Pemerintahan Desa Gumuksari Kecamatan Kalisat Kabupaten Jember.

Key Words: Motivasi Kerja, Prestasi Kerja 


\section{PENDAHULUAN}

Dalam

menghadapi

era

globalisasi

dan

telah

diberlakukannya otonomi daerah

faktor sumber daya manusia sangat penting, artinya prinsip pengelolaan lembaga pemerintah kabupaten yang profesional, ramping dan diisi Aparatur Pemerintahan khususnya Aparatur Pemerintahan Desa yang punya prestasi kerja tinggi merupakan kebutuhan yang sangat mendesak.Kedudukan dan peran Aparatur Pemerintahan Desa sebagai unsur aparatur negara punya andil yang cukup besar dalam menentukan keberhasilan pembangunan nasional, baik pembangunan fisik maupun non fisik. Hal ini dilandasi suatu kenyataan bahwa Aparatur Pemerintahan Desa merupakan ujung tombak Pemerintah Kabupaten dan atau Pemerintah Pusat dalam melaksanakan tujuan nasional, sehingga tujuan pembangunan nasional untuk mewujudkan masyarakat adil dan makmur berdasarkan Pancasila dan UndangUndang Dasar 1945 ditentukan oleh pelaksanaan tugas yang diberikan kepada para Aparatur Pemerintahan Desa.

Dengan demikian peningkatan mutu kerja Aparatur Pemerintahan Desa pada masa pembangunan atau era otonomi daerah sekarang ini sangat diperlukan secara berkelanjutan. Diharapkan dalam peningkatan mutu kerja tersebut dapat diperoleh Aparatur Pemerintahan Desa yang benar benar mampu mengemban tugas pokok dan fungsi yang pada akhirnya dapat memperlancar dan mempercepat tercapainya tujuan pembangunan nasional. Aparatur Pemerintahan Desa yang dimaksud adalah Aparatur Pemerintahan Desa yang berwibawa, berdaya guna, bersih, loyal, penuh kesetiaan dan ketaatan pada Pancasila, UUD 1945, dan Negara Kesatuan Republik Indonesia diisi tenaga kerja yang ahli, mampu menjalankan tugas pokok dan fungsi dibidang masing masing dan hanya mengabdikan diri kepada kepentingan negara dan rakyat.

Memotivasi

Aparatur

Pemerintahan Desa secara terus menerus akan mampu meningkatkan 
hasil kerja Aparatur Pemerintahan Desa. Kebutuhan kerja serta hasil kerja Aparatur Pemerintahan Desa dapat dipengaruhi oleh faktor yang bersifat sosiologis maupun psikologis. Faktor sosiologis berkenaan dengan hubungan sosial antara Aparatur Pemerintahan Desa dalam suatu organisasi dengan lingkungan masyarakat.Seorang Aparatur Pemerintahan Desa sikap dan tingkah lakunya tidak dapat dilepaskan dari kondisi adat istiadat ataupun kebiasaan-kebiasaan lingkungan asalnya, karena itu hubungan sosial antara Aparatur Pemerintahan Desa dalam suatu organisasi dan hubungannya dengan lingkungan masyarakat merupakan faktor yang potensial bagi kepentingan suatu organisasi.Sedangkan faktor psikologis yaitu yang berkenaan dengan sifat - sifat dan kepribadian setiap Aparatur Pemerintahan Desa, baik statusnya sebagai pimpinan maupun staf. Walaupun kondisi lingkungan sudah tercipta dengan baik, tetapi kalau kondisi psikologis Aparatur Pemerintahan Desa kurang dapat menunjang maka akan berpengaruh terhadap proses kegiatan yang akhirnya akan mempengaruhi hasil kerja dalam pencapaian tujuan organisasi yang telah ditetapkan.

Berdasarkan pengamatan penulis, peranan motivasi yang sesuai bagi Aparatur Pemerintahan Desa belum berhasil baik dalam meningkatkan hasil kerja. Hal ini bisa dilihat karena masih banyak kehadiran Aparatur Pemerintahan Desa yang sering terlambat atau tidak hadir tanpa keterangan, pulang lebih cepat dari jam kerja yang telah ditentukan, terlihat mondar mandir saat jam kerja, sering berbincangbincang yang tidak ada kepentingannya dengan tugas pokok dan fungsinya sehingga sangat merugikan dinas di mana mereka bekerja.

Aparatur Pemerintahan Desa Gumuksari menurut Peraturan Daerah Kabupaten Jember adalah abdi negara dan abdi masyarakat yang tugas pokok dan fungsinya disamakan dengan Pegawai Negeri Sipil, tetapi penghasilannya tidak sama. Dengan adanya otonomi daerah Bupati/Walikota bersama 
dengan DPRD/Kota membuat dan mengesahkan Peraturan Daerah yang menjadi pedoman/petunjuk bagi Bupati dalam melaksanakan tugastugasnya, yang selanjutnya peraturan daerah tersebut didelegasikan keseluruh Satuan Kerja Perangkat Daerah (SKPD) dan seluruh Kecamatan serta seluruh desa/kelurahan yang ada di kabupaten/kota tersebut.

Berdasarkan struktur organisasi pemerintah desa, seolah-olah kebutuhan kerja Aparatur Pemerintahan Desa sudah terpenuhi secara maksimal sehingga tugas pokok dan fungsi dari masingmasing bagian dari organisasi sudah berjalan dengan baik. Kenyataan yang terjadi di Desa Gumuksari Kecamatan Kalisat tidak seperti itu, misalnya rutinitas kehadiran/pulang kerja tidak tepat waktu, tugas pokok dan fungsinya yang brhubungan dengan pekerjaan yang menjadi tanggungannya masih menjadi permasalahan.

Dari gambaran di atas penulis memilih judul dalam penelitian ini adalah "HUBUNGAN MOTIVASI KERJA DENGAN PRESTASI

$\begin{array}{lr}\text { KERJA DI } & \text { PEMERINTAHAN } \\ \text { DESA } & \text { GUMUKSARI } \\ \text { KECAMATAN } & \text { KALISAT } \\ \text { KABUPATEN JEMBER". }\end{array}$

\section{TUJUAN PENELITIAN}

Adapun tujuan dari penelitian ini adalah"Untuk mengetahui adakah hubungan yang positif dan signifikan antara motivasi kerja dengan prestasi kerja di Pemerintahan Desa Gumuksari Kecamatan Kalisat Kabupaten Jember”.

\section{TINJAUAN PUSTAKA}

\subsection{Landasan Teori}

\section{a. Motivasi Kerja}

Pengertian motivasi ditafsirkan secara berbeda-beda oleh para ahli sesuai dengan tempat dan keadaan masing-masing, namun hakekatnya terdapat persamaan prinsip.

Menurut Cascio dalam Hasibuan (1999:95) motivasi adalah suatu kekuatan yang dihasilkan dari keinginan seseorang untuk memuaskan kebutuhan (lapar, haus, dan bermasyarakat).Sedangkan The Liang Gie (1972:265) menyatakan bahwa motivasi merupakan pekerjaan yang dilakukan oleh 
seseorang manajer dalam memberikan inspirasi, semangat dan dorongan kepada orang lain untuk menggiatkan orang-orang atau karyawan agar mereka bersemangat dan dapat mencapai hasil sebagaimana dikehendaki dari orang-orang tersebut.

Menurut Hasibuan (1999:95) motivasi adalah pemberian daya penggerak yang menciptakan kegairahan kerja seseorang, agar mereka mau bekerja sama, bekerja efektif dan terintegrasi dengan segala daya upaya untuk mencapai kepuasan. Motivasi juga dapat diartikan sebagai suatu dorongan dari dalam diri orang-orang untuk mengatasi segala tantangan dan hambatan dalam upaya mencapai tujuan (Davis, 1996:88).Gibson (1997:185) mengemukakan pendapatnya bahwa motivasi diartikan sebagai suatu kekuatan dorongan seseorang, karyawan yang menimbulkan dan mengarahkan perilaku, kemudian Koontz dalam Hasibuan (1999:95) menyatakan bahwa motivasi mengacu pada dorongan dan usaha untuk memuaskan kebutuhan atau suatu tujuan.

Dari pendapat-pendapat tersebut ditarik suatu kesimpulan bahwa motivasi merupakan bentuk kebutuhan seseorang untuk bertingkah laku, bagaimana perilaku dimulai, digiatkan, dipertahankan, diarahkan dan diberhentikan.Motivasi dapat juga diartikan sesuatu jawaban mengapa seseorang bersedia melakukan pekerjaan tertentu.Motivasi menyangkut reaksi berantai yaitu mulai adanya kebutuhan yang dirasakan, kemudian timbul kegunaan atau sasaran yang hendak dicapai, dan mencari usaha untuk mencapai sasaran, serta berakhir dengan kepuasan.

Menurut Miftah Thoha (1999:206) tiga kebutuhan menurut Mc. Clelland yaitu:

1) Kebutuhan akan prestasi Kebutuhan akan prestasi adalah kebutuhan yang memiliki rasa tanggung jawab yang tinggi terhadap pelaksanan suatu tugas atau mencari solusi atas suatu permasalahan.

2) Kebutuhan akan afiliasi 
Kebutuhan akanafiliasi merupakan suatu keinginan untuk melakukan hubungan bersahabat dan hangat dengan orang lain.

3) Kebutuhan akan kekuasaan

Kebutuhan akan kekuasaan adalah kebutuhan untuk mempengaruhi dan mengendalikan orang lain dan bertanggung jawab kepadanya.

\section{b. Prestasi Kerja}

Prestasi dapat diartikan sebagai ukuran keberhasilan usaha dengan memperhatikan efesiensi dan efektifitas.Sedangkan menurut Hasibuan (1999:75) prestasi kerja adalah suatu hasil kerja yang dicapai seseorang dalam melaksanakan tugas-tugasnya yang didasarkan atas kecakapan, usaha dan kesempatan.Jika ketiga faktor tersebut semakin baik maka prestasi kerja semakin tinggi.

Kerja menurut Google (di unduh 15 Nopember 2011) adalah sesuatu yang dikeluarkan oleh seseorang sebagai profesi yang dengan sengaja dilakukan untuk mendapatkan hasil kerja dan gaji. Sehingga kerja adalah kegiatan untuk melakukan dan memenuhi kebutuhan dasar dan bukan merupakan tujuan.Dalam hal ini kerja yang dimaksud adalah kerja yang dilaksanakan olehAparatur Pemerintahan Desa yang ada diDesa Gumuksari Kecamatan Kallisat Kabupaten Jember.

\section{c. Hubungan Motivasi Kerja Dengan Prestasi Kerja}

Berdasar pada proses motivasi tersebut diatas, sudah jelas bahwa motivasi kerja ada hubungannya dengan prestasi kerja, hal ini dapat diketahui dari faktor psikologis yaitu yang berkenaan dengan sifat dan kepribadian setiap Aparatur Pemerintahan Desa, baik statusnya sebagai pimpinan maupun staf. Sesuai dengan pendapat Choiri (1999:3) walau kondisi lingkungan sudah tercipta dengan baik, tetapi kalau kondisi psikologis Aparatur Pemerintahan Desa kurang dapat menunjang maka akan berpengaruh terhadap proses kegiatan yang akhirnya akan mempengaruhi prestasi kerja dalam pencapaian tujuan organisasi yang telah 
ditetapkan. Memotivasi Aparatur Pemerintahan Desa secara terus menerus akan mampu meningkatkan prestasi kerja. Motivasi serta prestasi kerja Aparatur Pemerintahan Desa dapat dipengaruhi oleh faktor yang bersifat sosiologis maupun psikologis.

Faktor sosiologis berkenaan dengan hubungan sosial antara Aparatur Pemerintahan Desa dalam suatu organisasi dengan lingkungan masyarakat. Seorang Aparatur Pemerintahan Desa sikap dan tingkah lakunya tidak dapat dilepaskan dari kondisi adat istiadat ataupun kebiasaan-kebiasaan lingkungan asalnya, karena itu hubungan sosial antara Aparatur Pemerintahan Desa dalam suatu organisasi dan hubungannya dengan lingkungan masyarakat merupakan faktor yang potensial bagi kepentingan suatu organisasi. Sedangkan faktor psikologis yaitu yang berkenaan dengan sifat dan kepribadian setiap Aparatur Pemerintahan Desa, baik statusnya sebagai pimpinan maupun staf. Walau kondisi lingkungan sudah tercipta dengan baik, tetapi kalau kondisi psikologis Aparatur Pemerintahan Desa kurang dapat menunjang maka akan berpengaruh terhadap proses kegiatan yang akhirnya akan mempengaruhi prestasi kerja dalam pencapaian tujuan organisasi yang telah ditetapkan.

Prestasi kerja tinggi berarti peranAparatur Pemerintahan Desa benar-benar dapat berfungsi sebagai penghasil kerja yang tepat guna dan berhasil guna sesuai dengan sasaran-sasaran organisasi yang hendak dicapainya. Apabila tujuan peningkatan prestasi kerja para Aparatur Pemerintahan Desadapat terpenuhi, maka target pekerjaan yang telah ditentukan akan tercapai dengan baik sesuai dengan ketentuan peraturan yang berlaku. Prestasi kerja tinggi berarti peranAparatur Pemerintahan Desa benar-benar dapat berfungsi sebagai penghasil kerja yang tepat guna dan berhasil guna sesuai dengan sasaran-sasaran organisasi yang hendak dicapainya. Apabila tujuan peningkatan prestasi kerja para Aparatur Pemerintahan Desa dapat 
terpenuhi, maka target pekerjaan yang telah ditentukan akan tercapai dengan baik sesuai dengan ketentuan peraturan yang berlaku.

\subsection{Kerangka Pemikiran}

Berdasar pada uraian beberapa teori yang telah penulis jelaskan diatas, telah disebutkan bahwa dalam penelitian ini yang penulis pilih adalah teori motivasi dari Mc Cleland, dengan pertimbangan bahwa teori dari Mc. Cleland tersebut dapat digunakan untuk memotivasi semua tingkatan pekerja atau Aparatur Pemerintahan Desa.

\subsection{Hipotesis}

Ha: Ada hubungan yang positif dan signifikan antara motivasi kerja dengan prestasi kerja di Pemerintahan Desa Gumuksari Kecamatan Kalisat Kabupaten Jember.

$\mathrm{H}_{0}$ : Tidak ada hubungan yang positif dan signifikan antara motivasi kerja dengan prestasi kerja di Pemerintahan Desa Gumuksari Kecamatan Kalisat Kabupaten Jember.

\section{METODE PENELITIAN}

Jenis penelitian ini adalah penelitian deskriptif dan analitikkuantitatif.Lokasi penelitian dilakukan di kantorPemerintahan Desa Gumuksari Kecamatan Kalisat Kabupaten Jember.

Populasi dalam penelitian ini adalah seluruh karyawan di kantorPemerintahan Desa Gumuksari Kecamatan Kalisat Kabupaten Jember. Penentuan sampel dalam penelitian ini menggunakan probability sampling dengan teknik simple random samplingyaitu 25 karyawan di kantorPemerintahan Desa Gumuksari Kecamatan Kalisat Kabupaten Jember.

Dalam pengambilan data menggunakan kuesioner.Analisis data menggunakan analisis deskriptif kuantitatif yaitu koefisien korelasi menggunakan Rank Spearman, sedangkan kriteria pengambilan keputusannya dapat dilihat dari besarnya koefisien korelasi setelah dilakukan perhitungan menggunakan SPSS 16 for Windows adalah $-1 \leq \mathrm{r} \leq$ 1. 


\section{HASIL PENELITIAN DAN PEMBAHASAN}

\subsection{Perhitungan Korelasi Rank Spearman}

Tabel 1.Perhitungan Korelasi Rank Spearman

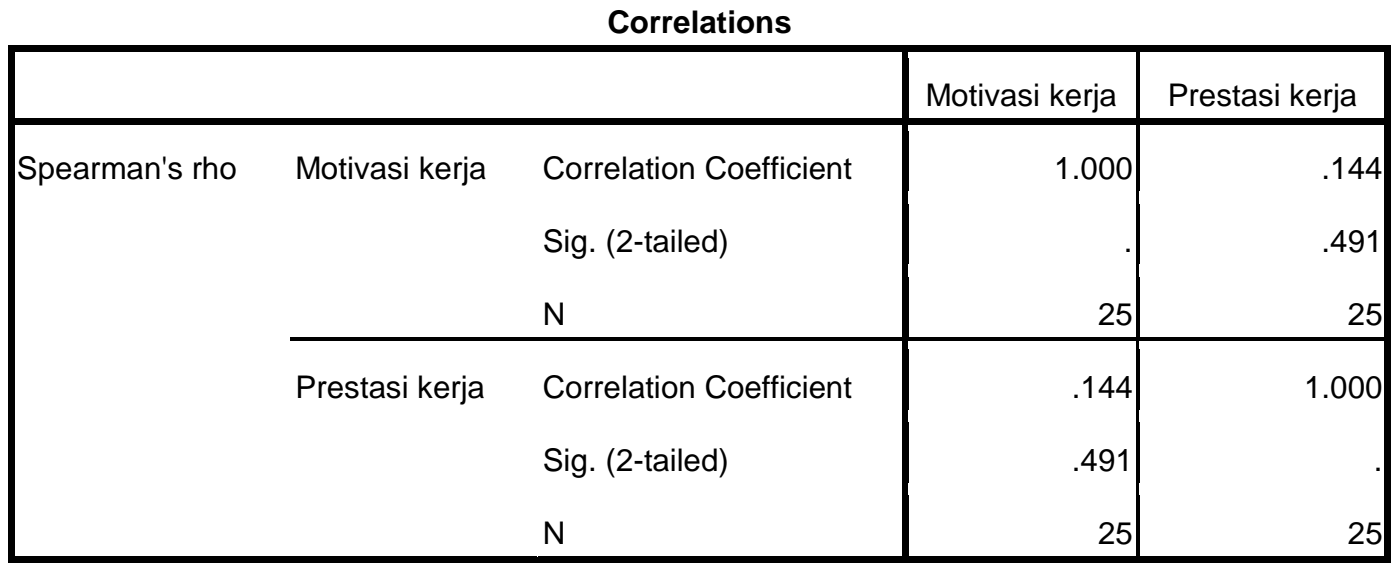

Berdasar pada perhitungan Gumuksari Kecamatan Kalisat Korelasi Rank Spearmans diperoleh Kabupaten Jember.

rs hitung sebesar 0,144 dengan jumlah $\mathrm{N}=25$, bila dikonsultasikan dengan interval korelasi maka rs hitung sebesar 0,144 terletak diantara $0,00-0,199$ dinyatakan bahwa mempunyai tingkat hubungan sangat rendah, ini berarti menerima hipotesis yang disampaikan yaitu menerima $\mathrm{Ha}$ dan menolak $\mathrm{H}_{0}$ artinya ada hubungan yang positif dan signifikan meskipun sangat rendah antara motivasi kerja dengan prestasi kerja di Pemerintahan Desa

\subsection{Perhitungan Uji t test}

Di dalam pengujian hubungan motivasi kerja dengan prestasi kerja di Pemerintahan Desa Gumuksari Kecamatan Kalisat Kabupaten Jember berdasar pada perhitungan korelasi tersebut menunjukkan bahwa $\mathrm{Ha}$ diterima dan $\mathrm{H}_{0}$ ditolak, untuk membuktikan kesyahihan $\mathrm{Ha}$ diterima tersebut maka langkah selanjutnya adalah melakukan dengan uji $\mathrm{t}$ test seperti pada tabel berikut. 
Tabel 2.Perhitungan Uji t test

\begin{tabular}{|c|c|c|c|c|c|c|}
\hline \multicolumn{7}{|c|}{ Coefficients $^{a}$} \\
\hline \multirow{2}{*}{\multicolumn{2}{|c|}{ Model }} & \multicolumn{2}{|c|}{ Unstandardized Coefficients } & \multirow{2}{*}{$\begin{array}{c}\begin{array}{c}\text { Standardized } \\
\text { Coefficients }\end{array} \\
\text { Beta }\end{array}$} & \multirow[b]{2}{*}{$\mathrm{t}$} & \multirow[b]{2}{*}{ Sig. } \\
\hline & & $\mathrm{B}$ & Std. Error & & & \\
\hline \multirow[t]{2}{*}{1} & (Constant) & 71.436 & 4.072 & & 17.541 & .000 \\
\hline & Motivasi kerja & .073 & .092 & .162 & .787 & .439 \\
\hline
\end{tabular}

a. Dependent Variable: Prestasi kerja

Berdasar pada perhitungan uji $\mathrm{t}$ test maka diperoleh t hitung sebesar 0,787, bila dikonsultasikan dengan nilai-nilai dalam distribusi t dengan $\mathrm{N}-2=23$ maka didapatkan angka 0,687, ini berarti t hitung lebih besar dari t tabel $(0,787>0,687)$. Dengan demikian terbukti secara nyata bahwa $\mathrm{Ha}$ diterima dan $\mathrm{H}_{0}$ ditolak, maksudnya motivasi kerja mempunyai hubungan dan pengaruh yang positif dan signifikan dengan prestasi kerja di Pemerintahan Desa Gumuksari Kecamatan Kalisat Kabupaten Jember.

\section{KESIMPULAN}

Dari analisis data yang telah dilakukan diatas, maka diperoleh kesimpulan sebagai berikut:

1) Dengan perhitungan korelasi rank spearman diperoleh rs hitung 0,144 yang terletak pada interval korelasi antara 0,000,199 mengandung arti mempunyai hubungan yang sangat rendah, berarti ada hubungan yang positif dan signifikan antara motivasi kerja dengan prestasi kerja di Pemerintahan Desa Gumuksari Kecamatan Kalisat Kabupaten Jember.

2) Merujuk padaperhitunganuji t test maka terbukti bahwat hitung lebih besar darittabel yaitu $(0,787>0,687)$ berarti ada hubungan motivasikerja denganprestasi kerja yang nyata di Pemerintahan Desa Gumuksari Kecamatan Kalisat Kabupaten Jember.

DAFTAR PUSTAKA 
Arikunto, Suharsini, 2002, Prosedur Penelitian Suatu Pendekatan Praktek, Jakarta; RinekaCipta

Davis, Keith, John W, Newstor, 1996, Perilaku Dalam Organisasi, Edisi Ketujuh,Jakarta;Erlangga.

Gibson, James, John M. Ivencevich, James H. Donnely, Jr, 1997, Organisasi(Perilaku StrukturProses), Jilid II, Terjemahan, Edisi kedelapan,Jakarta; Binarupa Aksara.

Gie, The Liang, 1972, Kamus Administrasi,Jakarta; Gunung Agung.

Hasibuan, Malayu SP, 1999, Organisasi dan Motivasi, Bandung; Bumi Aksara.

Koentjaraningrat, 1991, Metodemetode Penelitian Masyarakat,Jakarta; PT. Gramedia PustakaUtama.

Kotler, Philip, 2000, Marketing Management.(Edisi Indonesia oleh Hendra Teguh, Ronny dan Benjamin Molan), Jakarta: PT. Indek.

Miftah, Thoha, 1999,Perilaku Organisasi (Konsep Dasar dan Aplikasinya),Jakarta;

CV.Rajawali.

Manullang, M, 1981, Manajemen personalia, Jakarta; Ghalia Indonesia.

Musanef, 2001.Manajemen Kepegawaian di Indonesia, Jakarta; PT. Gunung Agung.

Nainggolan, 1982, Pembinaan Pegawai Negeri Sipil, Jakarta; PT. Nutu.

Nasir, M. 2003, Metode Penelitian, Jakarta; Ghalia Indonesia.
Rao, TV, 1982, Penilaian Prestasi Kerja, Jakarta; PT. Binaman Presindo.

Surachmad, Winarno. 2004, Dasar dan Tehnik Research, Bandung; Transito.

Sugiyono, 2010, Metode Penelitian Administrasi, Bandung; Alfabeta.

Umar, H. 2004, Metode Riset Ilmu Administrasi, Jakarta, Penerbit Gramedia.

Nainggolan, 1982, Pembinaan Pegawai Negeri Sipil, Jakarta; PT. Nutu.

Rao, TV, 1982, Penilaian Prestasi Kerja, Jakarta; PT. Binaman Presindo. 